\title{
"Effort expectancy and social influence factors as main determinants of performance expectancy using electronic banking"
}

\begin{tabular}{|c|c|}
\hline AUTHORS & $\begin{array}{l}\text { Igor Fedorko (iD } \\
\text { Radovan Bačik (iD } \\
\text { R } \\
\text { Beata Gavurova (i) } \\
\text { R }\end{array}$ \\
\hline ARTICLE INFO & $\begin{array}{l}\text { Igor Fedorko, Radovan Bačik and Beata Gavurova (2021). Effort expectancy and } \\
\text { social influence factors as main determinants of performance expectancy using } \\
\text { electronic banking. Banks and Bank Systems, 16(2), 27-37. } \\
\text { doi:10.21511/bbs.16(2).2021.03 }\end{array}$ \\
\hline DOI & http://dx.doi.org/10.21511/bbs.16(2).2021.03 \\
\hline RELEASED ON & Wednesday, 28 April 2021 \\
\hline RECEIVED ON & Wednesday, 13 May 2020 \\
\hline ACCEPTED ON & Monday, 26 April 2021 \\
\hline LICENSE & $\begin{array}{l}(c)) E Y \\
\text { This work is licensed under a Creative Commons Attribution } 4.0 \text { International } \\
\text { License }\end{array}$ \\
\hline JOURNAL & "Banks and Bank Systems" \\
\hline ISSN PRINT & $1816-7403$ \\
\hline ISSN ONLINE & $1991-7074$ \\
\hline PUBLISHER & LLC "Consulting Publishing Company "Business Perspectives" \\
\hline FOUNDER & LLC "Consulting Publishing Company "Business Perspectives" \\
\hline
\end{tabular}

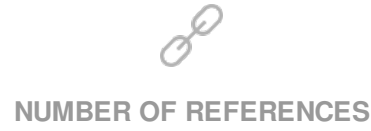

26

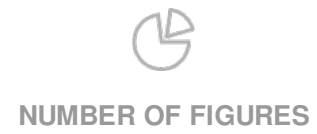

3
NUMBER OF TABLES

8

(C) The author(s) 2021. This publication is an open access article. 


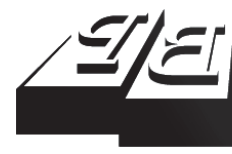

\section{BUSINESS PERSPECTIVES}

(O)

LLC "CPC "Business Perspectives" Hryhorii Skovoroda lane, 10, Sumy, 40022, Ukraine www.businessperspectives.org
Received on: $13^{\text {th }}$ of May, 2020 Accepted on: $26^{\text {th }}$ of April, 2021 Published on: $28^{\text {th }}$ of April, 2021

(C) Igor Fedorko, Radovan Bacik, Beata Gavurova, 2021

Igor Fedorko, Ph.D., Assistant Professor, Faculty of Management, The University of Presov in Presov, Slovakia. (Corresponding author)

Radovan Bacik, Ph.D., Associate Professor, Faculty of Management, University of Presov in Presov, Slovakia.

Beata Gavurova, Ph.D., Professor, Faculty of Mining, Ecology, Process Control and Geotechnologies, Technical University of Košice, Slovakia.
EFFORT EXPECTANCY AND SOCIAL INFLUENCE FACTORS AS MAIN DETERMINANTS OF PERFORMANCE EXPECTANCY USING ELECTRONIC BANKING

\begin{abstract}
This study is aimed at determining the effect of expected effort and social influence factors on expected performance when using internet banking. The study adapts the constructs and definitions from the UTAUT model in the context of the adaptation of online banking technology. With regard to the nature of the variables analyzed, the following statistical tests and methods were used: calculation of average values using descriptive statistics; multiple linear regression analysis - to interpret associations between quantitative variables. Banks, as well as users of these banking services in the online environment, are the subject of research. The survey sample consists of 454 men and women and reflects the profile of online consumers across different countries of the European Union. The results of this study show the impact of the social influence construct on the respondents' behavior when using electronic banking. The expected effort factor in the study significantly affects the expected performance factor, which can be characterized by original research, which showed that the effect of perceived ease of use on behavioral intent and use is incompatible with the degree of system complexity.
\end{abstract}

\section{Keywords}

electronic banking usage, technology acceptance model, user behavior

\section{JEL Classification $\quad$ M31, M50, M15}

\section{INTRODUCTION}

Since its inception, internet banking has changed not only the banking sector, but also the banking services provided to customers (Iyengar \& Belvalkar, 2010). The incentive to implement internet banking opens up new business opportunities, attracting additional funds from both new and existing customers, expanding geographic coverage, and, last but not least, the image of a modern bank, especially if an institution is aimed at a young audience and does not want to risk losing customer loyalty (Zamir, 2019). The explosion of the internet use and the enormous funding of e-banking initiatives have attracted researchers to explore the issues of internet banking (Belas et al., 2015). Its growing use and general interest have led many internet analysts to believe that the technology will have a major impact on how financial institutions do business in the future (Wang et al., 2003). Through online banking, customers can conduct a wide range of operations electronically on the bank's homepage. This means for the bank's customers that internet banking provides a useful channel for managing financial transactions. Internet banking provides a sophisticated financial management tool that can be accessed quickly (Tan, 2000). Technology Acceptance Model (TAM) is a widely used model introduced by Davis in 1989. It is an extension of Theory of Reasoned Action (TRA). TAM 
specifies the adoption models of information systems. The aim of this model is answer the question of how users accept technology. The model shows that a number of factors influence user decisions on how and when to accept new technologies. According to Davis (1989), perceived usefulness is the degree to which an individual believes that using a particular system will increase his or her work productivity. It also defines perceived ease of use as the degree to which a person believes that the use of a particular system will be effortless. Another study of the use of technology is based on the Technology Acceptance Model (Davis, 1989). While the original purpose of the Technology Acceptance Model is to simulate the use of technology in simulated conditions, researchers have also applied TAM in consumer acceptance studies in online environment, such as mobile internet services (Jiang, 2009). The Unified Theory of Acceptance and Use of Technology - UTAUT (Venkatesh et al., 2003) is based and extended by TAM in an effort to integrate the eight most widely used technology acceptance research models into one practical model. Thus, UTAUT includes a framework for current Internet banking adoption studies. Al Queisi et al. (2014) adapt UTAUT constructs and definitions to the issue of consumer acceptance of technology and the context of its use. Expected performance is the degree to which the use of technology helps a consumer perform certain activities. The expected effort is the ease with which consumers benefit from technology. The social effect means the degree to which consumers believe that their loved ones (family and friends) think they should use the technology. This study aims to explain the relationships between the variable effort expectancy factor and social influence factor on the performance expectancy in a model based on the Unified Theory of Acceptance and Use of Technology model. These factors seek to explain user behavior in relation to the use of Internet banking.

Banking institutions, as well as other companies and individuals, benefit from well-designed websites, effective social networking and mobile marketing. The efficiency and quality provided by banks significantly affect not only all aspects of people's daily life, but also the country's economic growth (Kočišová, 2020). Based on an analysis of previous research on technology acceptance models, the purpose of this study is to clarify the significance of the selected factors, the so-called expected effort, social impact and expected results in relation to the use of internet banking in the light of a unified theory of acceptance and use of technology.

\section{LITERATURE REVIEW}

The UTAUT model (Venkatesh et al., 2003), which is based on the widespread principle of the TAM Technology Acceptance Model (Davis, 1989), consists of four key constructs affecting the behavioral intent and real use of technology. Performance expectancy is the degree to which the use of technology helps consumers perform certain actions. The effort expected is equivalent to the ease with which consumers use technology. Social effect refers to the degree to which consumers believe that their loved ones, such as family, think they should use the technology (Brown \& Venkatesh, 2005; Venkatesh et al., 2003).

The aim of the study is to identify the impact of expected effort and social influence factors on expected performance in the context of using internet banking. The study aims to explain how these elements affect user behavior. The study adapts constructs and definitions from the UTAUT model in the context of adapting of online banking technology.

According to Unified Theory of Acceptance and Use of Technology Theory, factors like performance expectancy, effort expectancy and social factors influence the intention to use technology. Research will focus on constructs that shape the intent to use internet banking technology.

Al-Qeisi et al. (2014) extend the UTAUT model by discovering the relationships between expected performance, expected effort and social influence. Based on a study of the relationship between performance and effort factors, Brown and Venkatesh (2005) define expected performance as the level to which the use of online banking assists users in performing e-banking operations. E-banking activities and other possibilities of using e-technologies, including ones in accounting 
systems, cause competitive advantages for different types of firms, in particular, SMEs (Budiarto et al., 2019). Considering the expected efforts, Pakurár et al. (2019) proved that training and developing employees to solve current problems and motivating talented employees to innovate can be an essential driver in increasing performance. The same effect can be achieved by correct usage of benefits and compensation practices (Bilan et al., $2020 \mathrm{~b}$ ) and socioeconomic support of employees (Majetić et al., 2019), which, in turn, are perceived by workers as an essential incentive for performance growth even in emerging markets with labor-deficient conjuncture regarding high-skilled employees (Bilan et al., 2020a). According to AlQeisi et al. (2014), performance expectation can also affect the expected effort or ease with which users believe they can conduct internet banking operations. Thus, the following hypothesis is put forward:

\section{H1: Expected efforts have a significant impact on expected performance.}

Brown and Venkatesh (2005) have identified the relationship between social impact and expected performance as the extent to which respondents believe that their loved ones think they should use internet banking. A study by Al-Queisi et al. (2014) expects the relationship between social impact and expected performance, but its results do not support this hypothesis. These findings are not typical for young entrepreneurs, whose incentives and results are derived by the social impact to a great extent (Rahmatiah et al., 2019). In their study, Kim and Park (2011) state that the stronger the social impact of an individual, the sooner the consumer will adapt to the new technology.

Thus, the following is hypothesized:

\section{H2: Social impact significantly affects the expect- ed performance.}

\section{MATERIALS AND METHODS}

To obtain the necessary primary sources of information and data for this study, the exploratory method, i.e. questionnaires, was used.
Questionnaires gather data based on subjective answers of respondents, which, in this study, are internet users and mobile application users who are also users of electronic banking services. The aim of the questions is to sort out the analyzed sample for subsequent statistical analysis. This study is interested in demographic information and data related to the use of internet, internet banking, mobile applications, so respondents can be placed into individual segments in terms of segmentation of the internet market. In addition, the study is aimed at exploring respondents' attitudes and views on internet marketing communication tools, the use of social networks, the use of selected applications in connection with mobile marketing and the impact of these aspects on their attitudes to the use of internet banking and bank themselves. With regard to the nature of the variables analyzed, the following statistical tests and methods were used:

- Calculation of average values using descriptive statistics.

- Cronbach's alpha and the Kaiser-Meyer-Olkin test were used to measure the adequacy of the research sample, statistically testing whether partial correlations between variables were low.

- Multiple linear regression analysis was performed to interpret associations between quantitative variables.

\section{- Structural Equation Modeling.}

The research subject are banks operating their own web portals, provide electronic banking services and offer mobile banking options through mobile applications, as well as users of these banking services in the online environment, visitors to the banking institutions' websites who represent real and potential users of electronic banking and users of mobile applications of these subjects.

Internet and mobile users are the basic set for quantitative research. Easier access to computer devices, technological advances and the ever-increasing popularity of smartphones give people the opportunity to use the Internet more often and more comfortably. The sample was compiled 
by proportional stratified sampling. Respondents were selected using the proportional stratified selection in each age group based on the age structure of internet banking users in the European Union (ComScore, online). The research sample consists only of respondents who are actively using mobile platforms for mobile banking purposes (one of the questions in the questionnaire).

A pilot survey on a sample of 38 respondents, students and university staff was also a useful tool for verifying the quality of the survey sample selection. The pilot survey, which was conducted in two phases, helped to verify the respondents' understanding of each question and the functionality in terms of instructions and the time it took to elaborate the questionnaire. As the research employed factor analysis, it was necessary to verify choice of questions, as well as question areas to see whether individual factors showed some common characteristics.

The reliability of the research file was tested in several ways. During retesting, the same questionnaire survey was distributed to the same respondents, and the degree of agreement between observations was recorded. The match rate between the two results was expressed as a correlation coefficient, with a value above 0.80 for all results. Since the survey does not include dichotomous items but features a larger scoring range (1 to 7 ), the focus was placed on the Cronbach alpha coefficient. Another assumption needed to be observed was factorability - an assumption that there are at least some correlations between variables in order for coherent factors to be identified. In principle, there should be some degree of collinearity between variables, but not to an extreme degree or singularity between variables. Factorability in terms of sample adequacy was addressed by the Kaiser-Meyer-Olkin (KMO) test the result of which should be greater than 0.5. Indeed, the result was greater than the required value. A total of 529 respondents' responses were recorded, of which 454 were accepted. The survey sample consists of 279 (61.45\%) men and 175 (38.55\%) women, the majority of the survey sample reaches a higher level of education, and 158 (34.80\%) belong to the age group of 19 to 29 years old. The relatively highly educated respondents and the moderate male dominance in the survey sample show the online consumer profiles across the European Union (Yousafzai \& Yani-de-Soriano 2012; Al-Qeisi et al., 2014).

\section{RESULTS}

The first defined factor is the expected performance. The respondents were asked about the issue of expected performance in different ways. The respondents could choose their answer on a seven-degree scale, with the lowest degree expressing total disagreement and the highest degree expressing full agreement with the statement.

The first set of questions concerned the performance expectancy (PE), which can be defined as the level to which an individual believes that using online banking will assist him in completing banking challenge through this platform (Venkatesh et al., 2003). The questions used in the survey were as follows (PE 1-5):

\section{PE 1: I have found that internet banking is useful to me.}

- PE 2: Internet banking helps me to accomplish my tasks faster.

- PE 3: Internet banking increases the efficiency with which I am performing bank-related tasks.

- PE 4: Internet banking improves the quality of banking services.

- PE 5: Internet banking improves my performance.

Questions regarding this factor examined the perceived performance of Internet banking by a respondent. As can be seen in Figure 1, the highest proportion of responses was positive or expressed agreement with the statements, while respondents answered positively in $80 \%$ of cases. Questions PE4 and PE5 recorded more ambiguous positive answers and more neutrally directed answers, which can be explained by the respondent's subjective feeling that Internet banking is not yet directly associated with the quality of services provided by banks. 


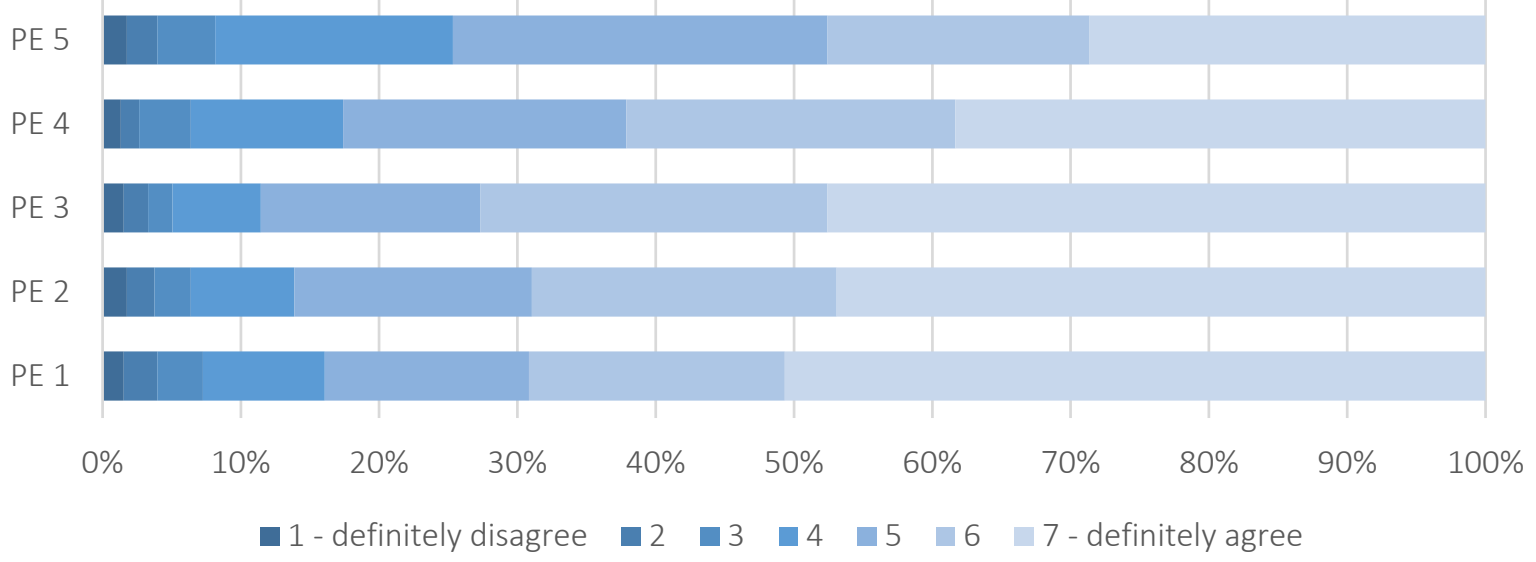

Figure 1. Results for the factor of expected performance

Table 1. Results for the expected performance factor

\begin{tabular}{|c|c|c|c|c|c|c|c|}
\hline & & & & & & & $\mathrm{n}$ proces \\
\hline & 1 & 2 & 3 & 4 & 5 & 6 & 7 \\
\hline Factor & $(\%)$ & $(\%)$ & $(\%)$ & $(\%)$ & $(\%)$ & (\%) & (\%) \\
\hline & $\mathbf{N}$ & $\mathbf{N}$ & $\mathbf{N}$ & $\mathbf{N}$ & $\mathbf{N}$ & $\mathbf{N}$ & $\mathbf{N}$ \\
\hline$D E 1$ & 1.54 & 2.42 & 3.30 & 8.81 & 14.76 & 18.50 & 50.66 \\
\hline PE 1 & 7 & 11 & 15 & 40 & 67 & 84 & 230 \\
\hline PE? & 1.76 & 1.98 & 2.64 & 7.49 & 17.18 & 22.03 & 46.92 \\
\hline PE 2 & 8 & 9 & 12 & 34 & 78 & 100 & 213 \\
\hline & 1.54 & 1.76 & 1.76 & 6.39 & 15.86 & 25.11 & 47.58 \\
\hline PE 3 & 7 & 8 & 8 & 29 & 72 & 114 & 216 \\
\hline DE $A$ & 1.32 & 1.32 & 3.74 & 11.01 & 20.48 & 23.79 & 38.33 \\
\hline PE 4 & 6 & 6 & 17 & 50 & 93 & 108 & 174 \\
\hline & 1.76 & 2.20 & 4.19 & 17.18 & 27.09 & 18.94 & 28.63 \\
\hline PE 5 & 8 & 10 & 19 & 78 & 123 & 86 & 130 \\
\hline
\end{tabular}

Note: Legend: 1 - I totally disagree; 3 - Neutral stance; 7 - I totally agree.

Another set of questions addressed the expected effort factor (EE - Effort expectancy), which is characterized as a degree of simplicity associated with the use of internet banking (Venkatesh et al., 2003). The items used in the survey were as follows (EE 1-4):

- EE 1: The use of internet banking is clear to me.

- $\quad$ EE 2: I am skilled in using internet banking.

- EE 3: It is easy for me to learn how to use internet banking.

- EE 4: It is easy for me to navigate through internet banking and make it do what I want.
The expected effort factor reflects the respondent's user experience and his ability to handle individual tasks when using internet banking. As with the previous questions, positive responses and a high level of agreement with the statements were recorded. However, what can be seen in the results and the figure is that the trend is less clear and the respondents responded more evenly in terms of the scale of responses. For question EE 2 (30.18\%) and EE 4 (26.87\%), the highest proportion of responses was found in the 6th degree of the scale.

Social Influence (SI) was another factor incorporated into the research. It can be defined as the degree to which a person believes that their close (important) people believe they should 


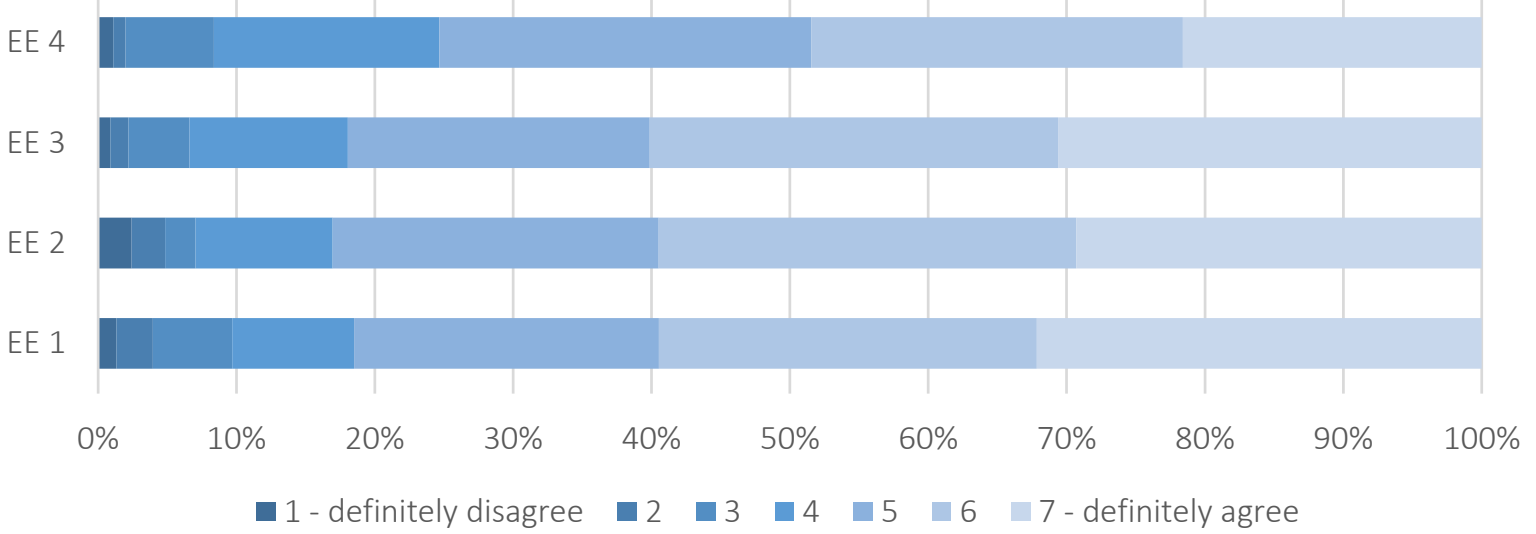

Figure 2. Summary of results for the expected effort factor

Table 2. Summary of results for the expected effort factor

\begin{tabular}{|c|c|c|c|c|c|c|c|}
\hline & & & & & & Sou & $\mathrm{n}$ proces \\
\hline & 1 & 2 & 3 & 4 & 5 & 6 & 7 \\
\hline Factor & (\%) & (\%) & (\%) & (\%) & (\%) & (\%) & (\%) \\
\hline & $\mathbf{N}$ & $\mathbf{N}$ & $\mathbf{N}$ & $\mathbf{N}$ & $\mathbf{N}$ & $\mathbf{N}$ & $\mathbf{N}$ \\
\hline FE 1 & 1.32 & 2.64 & 5.73 & 8.81 & 22.03 & 27.31 & 32.16 \\
\hline LL 1 & 6 & 12 & 26 & 40 & 100 & 124 & 146 \\
\hline FE? & 2.42 & 2.42 & 2.20 & 9.91 & 23.57 & 30.18 & 29.30 \\
\hline LL 2 & 11 & 11 & 10 & 45 & 107 & 137 & 133 \\
\hline $5[2$ & 0.88 & 1.32 & 4.41 & 11.45 & 21.81 & 29.52 & 30.62 \\
\hline LES & 4 & 6 & 20 & 52 & 99 & 134 & 139 \\
\hline FE $A$ & 1.10 & 0.88 & 6.39 & 16.30 & 26.87 & 26.87 & 21.59 \\
\hline Lᄃ 4 & 5 & 4 & 29 & 74 & 122 & 122 & 98 \\
\hline
\end{tabular}

Note: Legend: 1 - I totally disagree; 3 - Neutral stance; 7 - I totally agree.

use online banking. The factor also deals with and measures the support of bank employees in using internet banking (Venkatesh et al., 2003). The questions used in the survey were as follows (SI 1-5):

- SI 1: In the opinion of people important to me, I should use internet banking.

- SI 2: People who influence me believe I should use internet banking.

- SI 3: People with whom I share values think that I should use internet banking.

- SI 4: Bank staff are trying to help me using internet banking.

- $\quad$ SI 5: The bank branch I visit supports using internet banking.
With regard to the social influence factor, the first three questions dealt with the influence of the respondents' loved ones and their surroundings on their stance over the internet banking. With regard to the graphical representation of the results, the outcome shows mostly neutral attitude. The results show that respondents could not decide and therefore chose the neutral stance. Other responses are rather positive. Overall, half of the respondents chose to answer positively to the first question (50.22\%), and the same situation repeated for the second (53.30\%) and the third (55.07\%) question.

Questions SI 4 and SI 5 deal with the impact bank staff have on the respondent and his use of internet banking. These questions produced very positive responses. $29.74 \%$ of respondents totally agreed with the question whether bank employees are helpful with internet banking while the ques- 


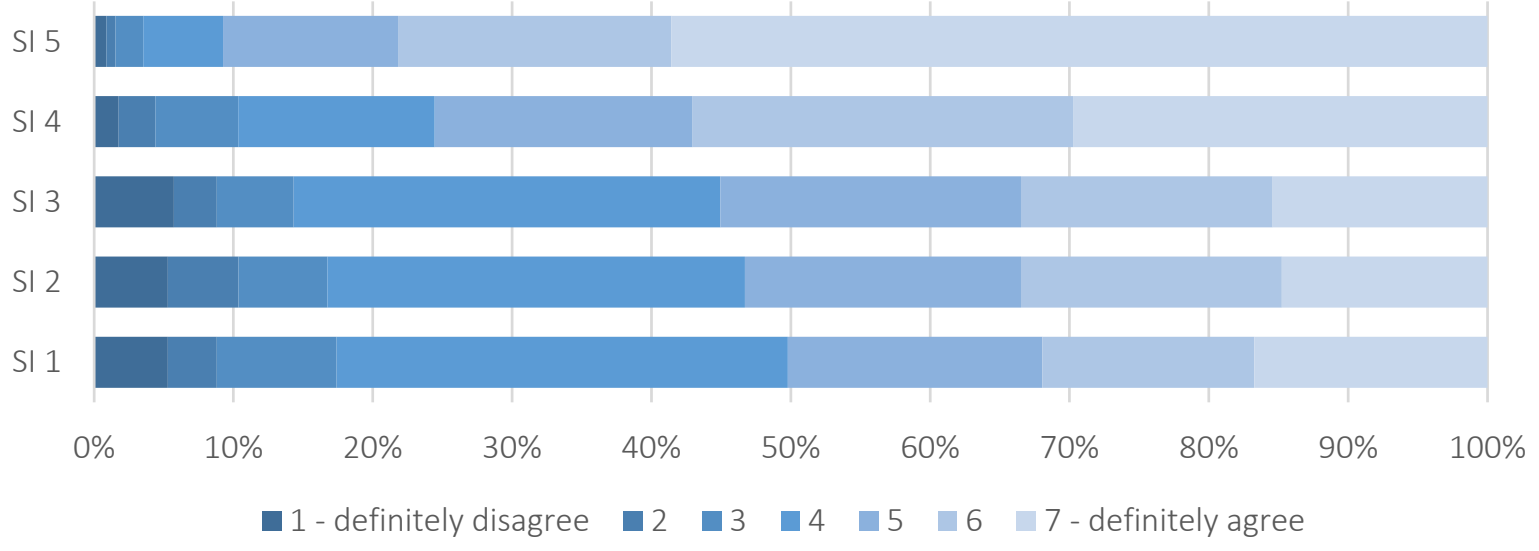

Figure 3. Overview of results for the social influence factor

Table 3. Results for the social influence factor

\begin{tabular}{|c|c|c|c|c|c|c|c|}
\hline & & & & & & & $n$ proce \\
\hline & 1 & 2 & 3 & 4 & 5 & 6 & 7 \\
\hline Factor & (\%) & (\%) & (\%) & (\%) & (\%) & (\%) & (\%) \\
\hline & $\mathbf{N}$ & $\mathbf{N}$ & $\mathbf{N}$ & $\mathbf{N}$ & $\mathbf{N}$ & $\mathbf{N}$ & $\mathbf{N}$ \\
\hline & 5.29 & 3.52 & 8.59 & 32.38 & 18.28 & 15.20 & 16.74 \\
\hline SI 1 & 24 & 16 & 39 & 147 & 83 & 69 & 76 \\
\hline $\mathrm{Cl}_{2}$ & 5.29 & 5.07 & 6.39 & 29.96 & 19.82 & 18.72 & 14.76 \\
\hline 312 & 24 & 23 & 29 & 136 & 90 & 85 & 67 \\
\hline $\mathrm{Cl} 2$ & 5.73 & 3.08 & 5.51 & 30.62 & 21.59 & 18.06 & 15.42 \\
\hline 513 & 26 & 14 & 25 & 139 & 98 & 82 & 70 \\
\hline CIA & 1.76 & 2.64 & 5.95 & 14.10 & 18.50 & 27.31 & 29.74 \\
\hline 514 & 8 & 12 & 27 & 64 & 84 & 124 & 135 \\
\hline CII & 0.88 & 0.66 & 1.98 & 5.73 & 12.56 & 19.60 & 58.59 \\
\hline 515 & 4 & 3 & 9 & 26 & 57 & 89 & 266 \\
\hline
\end{tabular}

Note: Legend: 1 - Totally disagree; 3 - Neutral stance; 7 - Totally agree.

tion on the support regarding the use of internet banking generated "totally agree" in $58.59 \%$ of respondents.

\subsection{Incorporating the construct into the UTAUT research model}

In the following part of this study, other factors that make up the structural model and the significance of their individual components with a view to its future optimization and the validity of the model were addressed. In the first evaluation column, there is $S t d . l v$, which represents standardized latent variables. In the next column, there is Std. all, which represents both standardized latent and observed variables. These values are often referred to as a complete standardized solution. Tables 4-6 provide an overview of factor values and reliability expressed by Cronbach alpha and Kaiser-MeyerOlkin statistics (KMOS).

The expected performance factor recorded the highest values for the following issues: faster completion of banking tasks, time efficiency in performing these tasks. Questions regarding the impact of electronic banking on the improved quality of banking services and improved respondent's performance of banking tasks received the lowest values. When verifying sample reliability, Cronbach Alpha reached a value of 0,912 .

The factor of expected efforts noted balanced values of significance on the first three issues concerning the clarity of using internet banking, 
Table 4. SEM for the PE factor - Overview of results for latent variables

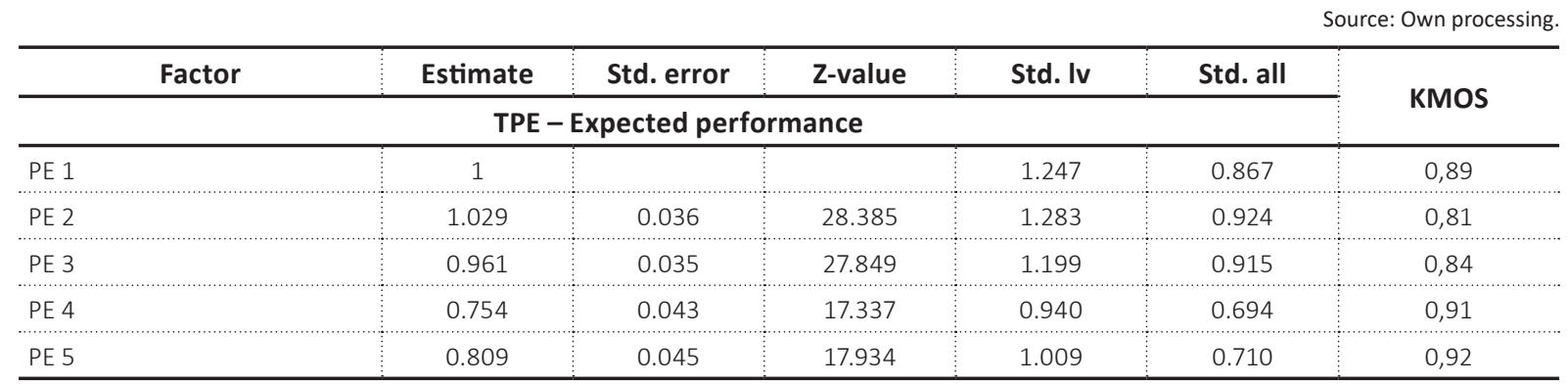

Table 5. SEM for the EE factor - Overview of results for latent variables

\begin{tabular}{|c|c|c|c|c|c|c|}
\hline Factor & Estimate & Std. error & Z-value & Std. Iv & Std. all & \\
\hline \multicolumn{6}{|c|}{ TEE - Estimated effort } & KIVIOS \\
\hline EE 1 & 1 & & & 1.220 & 0.868 & 0.858 \\
\hline EE 2 & 1.020 & 0.039 & 26.172 & 1.245 & 0.898 & 0.827 \\
\hline EE 3 & 0.943 & 0.036 & 25.898 & 1.151 & 0.892 & 0.833 \\
\hline EE 4 & 0.865 & 0.039 & 22.012 & 1.056 & 0.814 & 0.885 \\
\hline
\end{tabular}

skills in using it, and the ease of learning how to work with internet banking. The last question concerning the navigation in internet banking in relation to the user's intention was lower, but it can still be stated that the values reach similar numbers. When verifying sample reliability, Cronbach Alpha reached a value of 0,924 .

The first three questions regarding the social influence factor reflected respondents' views on the impact of individuals on the given respondent in relation to using internet banking, and in all three questions similar values were observed with the most significant change being bank branch staff and their assistance in using internet banking (0.426) and the support of banks when using internet banking (0.331). These questions will be excluded from the further evaluation. When verifying sample reliability, Cronbach Alpha reached 0.849 .

\subsection{Structural model and hypothesis testing}

After a detailed analysis of partial results, as part of the methods for calculating factor analysis, the research hypotheses were evaluated and the regression relationships between individual variables were observed. Detailed statistical values of the model can be found in the individual tables, which show the calculation coefficients for both methods used to calculate factor analysis.

The study on which the research is based used a robust ML estimation method that was also employed in the study in question. As can be seen, there are several factors showing significance. The expected effort factor positively and significantly affects the expected performance factor, and the social influence factor positively and significantly influences the expected performance factor at

Table 6. SEM for the SI factor- Overview of results for latent variables

\begin{tabular}{|c|c|c|c|c|c|c|}
\hline Factor & Estimate & Std. error & Z-value & Std. Iv & Std. all & \\
\hline \multicolumn{6}{|c|}{ TSI - Social influence } & KIVIOS \\
\hline SI 1 & 1 & & & 1.430 & 0.897 & 0.818 \\
\hline SI 2 & 1.071 & 0.031 & 34.126 & 1.532 & 0.962 & 0.718 \\
\hline SI 3 & 0.987 & 0.033 & 29.714 & 1.411 & 0.901 & 0.809 \\
\hline SI 4 & 0.439 & 0.046 & 9.589 & 0.628 & 0.428 & 0.687 \\
\hline SI 5 & 0.277 & 0.038 & 7.275 & 0.396 & 0.335 & 0.647 \\
\hline
\end{tabular}


Table 7. SEM when estimating ML - Overview of results for a structural regression model

\begin{tabular}{|c|c|c|c|c|c|c|}
\hline Variable & Estimate & Std. error & Z-value & \multirow{2}{*}{$p(>|z|)$} & \multirow{2}{*}{ Std.Iv } & \multirow{2}{*}{ Std.all } \\
\hline \multicolumn{4}{|c|}{ TPE } & & & \\
\hline TEE & 0.683 & 0.044 & 15.391 & 0.000 & 0.695 & 0.695 \\
\hline TSI & 0.094 & 0.032 & 2.979 & 0.003 & 0.111 & 0.111 \\
\hline
\end{tabular}

Table 8. Overview of statistical evaluation of research hypotheses

\begin{tabular}{l|c|c|c|c|c|c}
\hline Hypotheses & Route & Coefficient & S.E. & $\mathbf{t}(\mathbf{Z})$ & Result & Estimator \\
\hline H1 & TEE>TPE & 0.683 & 0.044 & 15.391 & Support & $\mathrm{ML}$ \\
\hdashline $\mathrm{H} 2$ & TSI>TPE & 0.094 & 0.032 & 2.979 & Support & $\mathrm{ML}$ \\
\hline
\end{tabular}

$p<0.01$. For the purposes of this paper, the null hypothesis was not explicitly defined as it represents a generally known relationship to the formulated alternative hypothesis, which expresses the existence of a difference. In each hypothesis, the influence of the independent variable on the dependent variable was observed. When evaluating hypotheses, the estimation methods are indicated in Table 8 with coefficients that always correspond to the given method.

For the first hypothesis, the impact of the expected effort factor (TEE) on the expected performance (TPE) was investigated. The hypothesis is as follows:

\section{H1: Expected efforts have a significant impact on expected performance.}

The coefficient for the effect of the expected effort factor on the expected performance is positive and statistically significant at a $\mathrm{p}<0.001$ level and a regression coefficient value of 0.683 . The hypothesis is thus accepted. The values are based on the ML estimation method.

\section{H2: Social influence significantly affects the ex- pected performance.}

Hypothesis $\mathrm{H} 2$ examines the significance of the social effect factor on the expected performance factor. The result of the investigation is positive, since a statistically significant coefficient of 0.110 at $p<0.001$ was reached. Thus, the hypothesis is accepted. The values are based on the ML estimation method.

\section{DISCUSSION}

The significance of the impact of the expected performance and expected effort factors is related to studies on the perceived ease of use and usefulness of the Technology Acceptance Model. The expected effort factor significantly affects the expected performance factor, which is in line with the original research, which indicated that the incidence of the ease of use factor on the behavioral intent and use (in this study, this factor corresponds to internet banking use) is inconsistent with the degree of the system complexity. In particular, ease of use influences usage or behavioral intent, particularly when technology seems more complicated and users are less skilled (Igbaria et al., 1997; Sun \& Zhang, 2006). The respondents who participated in the study are also users of electronic banking and, therefore, have experience in using the system. The impact of this factor, which represents the social effect of different groups of persons on the behavior of internet banking users, is not consistent with previous research in this area, since there is no evidence of the impact of this factor on the internet banking use. Previous research suggested that the impact of this factor is lost under the conditions of the voluntary use of technology, and thus users tend to prefer their own beliefs more than the views of other people or use their direct prior experience with the system to shape their opinion (Morris \& Venkatesh, 2000; Venkatesh et al., 2003). Karahanna and Straub (1999) argue that social standards have a greater impact on an unexperienced individual than on experienced potential users of these technologies. The results of the study show, in particular, the impact of the first 
three questions in the construct of social effect, namely the impact of important or close people on the respondent's behavior regarding the use of electronic banking. The results are subject to limitations, as are other survey-based studies. The results cannot prove causality, so further research in this area should focus on longitudinal research. In addition, the research was conducted in a particular industry, and, therefore, the results are limited to a specific area of internet banking. While there are clear advantages to such a specific area of research, care must be taken to generalize the results and apply them to other industries, other forms of technology, or other markets.

\section{CONCLUSION}

Based on the results, future research on the use of internet banking technology should focus on mobile banking, since this factor has proven to be an important attribute (UTAUT model) and its significance is expected to increase in the years to come in terms of user experience and ease of use of technology. As already mentioned, the subject of the research - banking institutions and their information systems used for internet banking for end consumers - is currently a very important topic. Many systems currently face accessibility problems for users, and thus there is a lot of room for improving and facilitating the operation of information systems in terms of user experience issues. This process may ultimately lead to easier adoption of the latest technology, acceptance of procedures and greater acceptance of the use of such technology.

\section{AUTHOR CONTRIBUTIONS}

Conceptualization: Igor Fedorko, Radovan Bacik.

Funding acquisition: Beata Gavurova.

Investigation: Igor Fedorko, Radovan Bacik.

Methodology: Igor Fedorko, Radovan Bacik.

Project administration: Igor Fedorko, Radovan Bacik, Beata Gavurova.

Software: Beata Gavurova.

Supervision: Beata Gavurova.

Validation: Igor Fedorko, Radovan Bacik.

Writing - original draft: Igor Fedorko.

Writing - reviewing \& editing: Igor Fedorko.

\section{REFERENCES}

1. Al-Qeisi, K., Dennis, Ch., Alamanos, E., \& Jayawardhena, Ch. (2014). Website design quality and usage behavior: Unified Theory of Acceptance and Use of Technology. Journal of Business Research, 67(11), 22822290. https://doi.org/10.1016/j. jbusres.2014.06.016

2. Belas, J., Koraus, M., \& Gabcova, L. (2015). Electronic Banking, Its Use And Safety. Are There Differences In The Access Of Bank Customers By Gender, Education And Age. International Journal of Entrepreneurial Knowledge, 3(2). https://doi.org/10.37335/ijek. v3i2.29
3. Bilan Y., Mishchuk, H., Roshchyk, I., \& Joshi, O. (2020a). Hiring and retaining skilled employees in SMEs: problems in human resource practices and links with organizational success. Business: Theory and Practice, 21(2), 780791. DOI: https://doi.org/10.3846/ btp.2020.12750

4. Bilan, Y., Mishchuk, H., Samoliuk, N., \& Mishchuk, V. (2020b) Gender discrimination and its links with compensations and benefits practices in enterprises. Entrepreneurial Business and Economics Review, 8(3), 189204. https://doi.org/10.15678/ EBER.2020.080311
5. Brown, S. A., \& Venkatesh, V. (2005). A model of adoption of technology in the household: A baseline model test and extension incorporating household life cycle. Management Information Systems Quarterly, 29(3), 11. https://doi. org/10.2307/25148690

6. Budiarto, D. S., Rahmawati, Bandi, \& Prabowo, M. A. (2019). Accounting information system and non-financial performance in small firm: Empirical research based on ethnicity. Journal of International Studies, 12(1), 338-351. doi:10.14254/2071$8330.2019 / 12-1 / 23$ 
7. Davis, F. D. (1989). Perceived usefulness, perceived ease of use, and user acceptance of information technology. Management Information Systems Quarterly, 319-340. https://doi. org/10.2307/249008

8. Heshan, S., \& Zhang, P. (2006). The role of moderating factors in user technology acceptance. International Journal of HumanComputer Studies, 64(2), 5378. https://doi.org/10.1016/j. ijhcs.2005.04.013

9. Igbaria, M., Zinatelli, N., Cragg, P., \& Cavaye, A. L. M. (1997). Personal computing acceptance factors in small firms: a structural equation model. Management Information Systems Quarterly, 21(3), 279-305. https://doi. org/10.2307/249498.

10. Jhumkee, I., \& Belvelkar, M. (2009). Case study of online banking in India: User behaviors and design guidelines. IFIP Working Conference on Human Work Interaction Design (pp. 180188). Springer, Berlin, Heidelberg, https://doi.org/10.1007/978-3642-11762-6_15

11. Karahanna, E., \& Detmar W. S. (1999). The psychological origins of perceived usefulness and ease-of-use. Information \& Management, 35(4), 237-250. https://doi.org/10.1016/s03787206(98)00096-2

12. Kočišová, K. (2020). TwoStage DEA: An Application in Banking. Lecture Notes in Networks and Systems, 129 LNNS. doi:10.1007/978-3-030-479459_162

13. Majetić, F., Makarovič, M., Šimleša, D., \& Golob, T. (2019). Performance of work integration social enterprises in Croatia, Slovenia, and Italian regions of Lombardy and Trentino. Economics and Sociology, 12(1), 286-301. doi:10.14254/2071789X.2019/12-1/17

14. Morris, M. G., \& Venkatesh, V. (2000). Age differences in technology adoption decisions: Implications for a changing work force. Personnel Psychology, 53(2), 375-403. https://doi. org/10.1111/j.1744-6570.2000. tb00206.x

15. Pakurár, M., Haddad, H., Popp J., Khan, T., \& Oláh, J. (2019). Supply chain integration, organizational performance and balanced scorecard: An empirical study of the banking sector in Jordan. Journal of International Studies, 12(2), 129-146. doi:10.14254/2071-8330.2019/12$2 / 8$

16. Pingjun, J. (2009). Consumer adoption of mobile internet services: An exploratory study. Journal of Promotion Management, 15(3), 418-454. https://doi. org/10.1080/10496490903196213

17. Rahman, A., Belas, J., Rosza, Z., \& Kliestik, T. (2017). Does bank ownership affect relationship lending: A developing country perspective. Journal of International Studies, 10(1), 277-288. https://doi. org/10.14254/2071-8330.2017/10$1 / 20$

18. Rahmatiah, Wiroto, D. W., \& Taan, H. (2019). Business continuity, motivation, and social conditions of young entrepreneurs. Economics and Sociology, 12(4), 166-182. https://doi.org/10.14254/2071789X.2019/12-4/10

19. Sang-Hoon, K., \& Jung Park, H. (2011). Effects of social influence on consumers' voluntary adoption of innovations prompted by others. Journal of Business Research, 64(11), 1190-1194. https://doi.org/10.1016/j. jbusres.2011.06.021

20. Shirley, T., \& Todd, P. (1995). Assessing IT usage: The role of prior experience. Management Information Systems Quarterly, 19(4), 561-570. https://doi. org/10.2307/249633

21. Tan, M., \& Teo, T. S. H. (2000). Factors influencing the adoption of Internet banking. Journal of the Association for information Systems, 1(1), 5. https://doi. org/10.17705/1jais.00005

22. Tung, H. T., Belas, J., \& Baideldinova, T. (2018). How do banks implement the capital regulation requirement?
Journal of International Studies, 11(3), 161-175. https://doi. org/10.14254/2071-8330.2018/11 $3 / 14$

23. Venkatesh, M., \& Davis, D. (2003). User acceptance of information technology: Toward a unified view. Management Information Systems Quarterly, 27(3), 425-478. https:// doi.org/10.2307/30036540

24. Venkatesh, V., \& Fred, F. D. (2000). A theoretical extension of the technology acceptance model: Four longitudinal field studies. Management Science, 46(2), 186-204. https://doi.org/10.1287/ mnsc.46.2.186.11926

25. Wang, Yi-Shun, Yu-Min, W., Hsin-Hui, L., \& Tzung-I, T. (2003). Determinants of user acceptance of Internet banking: an empirical study. International Journal of Service Industry Management, 14(5), 501-519. https://doi. org/10.1108/09564230310500192

26. Zamir, Z. (2019). The Impact of Knowledge Capture and Knowledge Sharing on Learning, Adaptability, Job Satisfaction and Staying Intention. International Journal of Entrepreneurial Knowledge, 7(1), 46-64. https:// doi.org/10.2478/ijek-2019-0004 